NBER. WORKING PAPER SERIES

SHORT-TERM AND LONG-TERM EXPECTATIONS OF THE

YEN/DOLLAR EXCHANGE RATE:

EVIDENCE FROM SURVEY DATA

Jeffrey A. Frankel

Kenneth A. Froot

Working Paper No. 2216

NATIONAL BUREAU OF ECONOMIC RESEARCH

1050 Massachusetts Avenue

Cambridge, MA 02138

Apri1 1987

This paper was written while the authors were participants at the National Bureau of Economic Research 1986 Summer Institute and while they were Visiting Scholars at the International Finance Division, Board of Governors of the Federal Reserve System, Washington, D.C. 20551. They would like to thank, in addition to these institutions, the Sloan Foundation, the Institute of Business and Economic Research at U.C. Berkeley, and the National Science Foundation (under grant no. SES-8218300) for research support. Views expressed are those of the authors. The research reported here is part of the NBER's research program in International Studies. Any opinions expressed are those of the authors and not those of the National Bureau of Economic Research. 
NBER Working Paper \#2216

April 1987

\title{
Short-Term and Long-Term Expectations of the Yen/Dollar Exchange Rate: Evidence from Survey Data
}

\begin{abstract}
$\underline{\text { ABSTRACT }}$
Three surveys of exchange rate expectations allow us to measure directly the expected rates of return on yen versus dollars. Expectations of yen appreciation against the dollar have been (1) consistently large, (2) variable, and (3) greater than the forward premlue, implying that Investors were willing to accept a lower expected return on dollar assets. At short-term horizons expectations exhibit bandwagon effects, while at longer-term horlzons they show the reverse. A 10 percent yen appreclation generates the expectation of a further appreciation of 2.4 percent over the following week, for example, but a depreciation of 3.4 percent over the following year. At any horizon, investors yould do better to reduce the absolute magnitude of expected depreciation. The true spot rate process behaves more like a random walk.
\end{abstract}

Jeffrey A. Frankel

Department of Economics University of California

Berkeley, CA 94720
Kenneth A. Froot

Sloan School of Management

MIT

Cambridge, MA 02139 


\section{Introduction}

W1th most of Japan's restrictions on International capital flows recently removed, the yen is now properly thought of as subject to the asset-warket model or exchange rates: the demand for yen versus dollars responds instantaneously to the expected rates of return on the two assets. The most evident component or variation in recent years has been interest. rates. The differential between U.S. and Japanese interest rates can be used to explain the Increased derand for dollars and the sharp appreciation of the dollar agalnst the yen from 1979 to 1984, and the subsequent reversal in 1985-86.2 But the other major determinant of the expected return differential, the expected rate of future appreclation of the yen, $1 s$ much less eas1ly observed than interest rates.

One view is that the expected rate of depreciation can be measured by the discount in the forward market. According to this view,

IThis paper was written while the authors were particlpants at the National Bureau of Economlc Research 1986 Sumer Institute and while they were Visiting Scholars at the International Flnance Division, Board of Governors of the Federal Reserve System. Washington, D.C. 20551. They would I1ke to thank in addition to these institutes, the Sloan Foundation, the Institute of Business and Economic Research at U.C. Berkeley, and the National Sclence Founcation (under grant no. SES-8218300) for research support. views expressed are those of the authors. All data used in this paper are available from Ken Froot, Sloan School of :lanagement, MIT, Cambridge. MA 02139.

2 Many papers discuss the pole of the interest rates in determininz the yen/doliar excrange rate, es=ecially since the 1979-30 11beral1zation. Four examples are Amano (:J56), Isntyama (1985), Ito (1986), and Johnson and Loopesko $(1086)$. 
the 3 per cent yen-dollar forward discount that prevailed in the early 1980 s represented investors' expectations that the dollar would in the future depreclate, presumably back toward some equllibrlum level. An Implication is that Investors acting on this expectation - "speculators" -- had a lower demand for dollars durling the strong-dollar perfod than they would have had acting solely on the basts of the interest differential or other factors; In other words, speculation was stabllizing.

An alternative vlew is that the expected rate of depreclation is much closer to zero than to the forward discount. Many emplrical studies have found that the ratlonally, or mathematlcally, expected rate of depreciation is close to zero, (1.e.. that the exchange rate follows a random walk) so there is a prima facie case that the same is true of Investor expectations. If expected depreciation is zero ("stat Ic expectations"), then there is no stabilizing effect in the form of speculators selling a currency when it is strong. A more extreme view is that there is a bandwagon effect: at each point during the 1980-84 period, the appreclation of the dollar against the yen generated expectations of further future appreciation, notwithstanding the fact that the dollar was selling at a forward discount against the yen. It would follow from this vlew that speculators --again, defined as investors acting on the basis of expectations of exchange rate changes-- drove the yen/dollar rate to a higher level than would have otherwise prevailed. It would follow that speculators have exaggerated the reverse swing in $1985-86$ as well. Whether expectations are stabilizing or destabllizing in this sense is one of the questions examined in this paper. 
Another question, which would be of particular interest to policy-makers if one were to conclude that exchange rates have been undesirably unstable, is whether government intervention in the foreign exchange market offers a way of affecting the exchange rate even in the absence of a change in macroeconomic policy. The question of whether Intervention can have an effect, even if sterilized so as to leave the money supply unchanged, is generally thought to depend on the question whether yen and dollar assets are imperfect substitutes in investors' portfollos. Under the special case in which assets are perfect substitutes, investors will be willing to absorb indefinitely-large quantities into their portfolios, as long as the assets pay the going rate of return, with no effect on the price of the asset. The condition one would like to test is uncovered interest parity: risk-neutral investors drive the yen interest rate into equality with the dollar interest rate corrected for expected depreciation.

Exchange rate expectations are cruclal for each of these 1mportant questions, and for others as well. Measuring investors' expectations is always difficult. Probably the most commonly-used measure of expected depreciation is the forward discount, which arbitrage (in the absence of barriers to capital flows) in turn equates to the interest differential. But using the forward discount or interest differential prejudges the question of perfect substitutability. The other comon approach is to assume that market expectations can be measured as the matheratical expectation of the realized exchange rate within the sample 
period, conditional on some particular information set. But this approach, too, prejudges much.

This paper proposes a third measure, survey data on exchange rate expectations, to answer various questions of interest regarding the yen/dollar market. The data come from three sources. The American Express Bank Revlew surveys 250-300 central bankers, private bankers, corporate treasurers, and economists once a year, with some surveys going back to 1976. The Economist's Financlal Report has conducted telephone surveys of currency traders and currency-room economists at 14 leading international banks each six weeks since June 1981. Money Market Services, Inc. (MMS), has also been surveying approximately 30 currency traders by telephone every two weeks since January 1983, and every week since October 1984. These data are discussed and analyzed in Frankel and Froot (1985) and Froot and Frankel (1986).3 The results reported in the present paper are new, in two respects. First, they focus exclusively on the yen/dollar rate, where the earlier two papers examined simultaneously the yen, pound, mark, French franc, and Swiss franc. Secondly, they distingulsh between short-term expectations on the one hand--at horizons of one week, two weeks or one month--as reported in the MMS survey, and long-term expectations on the other hand--at horlzons of $31 x$ months or twelve months--as reported in the other two surveys. The short-term and Iong-term expectations turn out to behave very differently.

3 The first paper investigates how investors form expectations from the contemporaneous spot rate and other variables. The second paper investigates the standard regression equation of exchange rate changes against the forward discount. Both papers include tests of the proposition that the expectations measured in the survey are unblased. 
In section 2 we relate expected depreciation as measured by the surveys to the forward discount, in order to test the hypothesis of perfect substitutability. In section 3 we investigate some standard models of expectations formation--distributed lag, adaptive, and regressive expectations. In each case one motivation is to see $1 f$ expectations are stabllizing, versus the alternative of static or even bandwagon expectations. In each case a second motivation, which we pursue in section 4, is to test whether the expectations formation process is similar to the process describing the mathematical expectation of the actual spot rate, that 1s, whether the expectations are unblased conditional on the particular information set. Included here is a test of the proposition that investors would do better in forming their expectations if they put more welght on the contemporaneous spot rate and less welght on other varlables. Finaliy, in section 5 we brlefly sumarize our findings.

II. The Forward D1scount: Risk Premlum or Expected Depreciation?

Our Pirst question is whether investors treat assets denominated 1. yen and dollars, as perfect substitutes. If positions in different currencles were perfectly substitutable, investors would be indifferent between holding open positions in forelgn assets and selling the assets forward. Th1s would 1mply that the forward discount exactly equals the expected depreciation of the currency:

(1)

$$
\underset{t+k}{e}=f d_{t}^{k}
$$


where $f d$ is the forward discount at term $k$ (the 108 of the current forward rate minus the $\log$ of the current spot rate) and $\Delta s_{t+k}^{e}$ is the 108 of the expected spot rate $k$ perlods into the future minus the 108 of the current spot rate. On the other hand, if investors need to be rewarded for exposure to the additional risk of holding an open position in the forelgn currency, they will demand a risk premium in addition to the forward rate:

$$
\Delta s_{t+k}^{e}=r d_{t}^{k}-r p_{t}^{k}
$$

Because both expected depreciation, $\Delta \mathbf{s}^{\mathbf{e}}$, and the risk premium, $r p$, are unobservable, additional information or assumptions are required to isolate them. If, for example, we were to assume that realized future spot rates are unblased measures of expected spot rates, then we could estimate expected depreciation (and therefore the risk premlum) erom the time-series of realized depreciation. 4 A second method of 1dentification would be to assume the validity of a particular model of investor portfol 10 optimization (such as Hodrick and Srivastava (1984) or Frankel (1982)) and use it to obtain estimates of the risk premium. A third approach, the one taken in this paper, is to employ survey data on expected depreciation. While surveys of agents' expectations may in many contexts be less desirable than data on their actual market behavior, the surveys are direct estimates that do not require us to assume any particular model of expected depreclation or of the risk premium.

\footnotetext{
${ }^{4}$ Perfect substitutability, or uncovered interest parity (which, given covered interest parity, is an equivalent condition), 1s tested for Japan versus the United States by Ito (1984) and McKenzie (1986).
} 
First we look at simple averages over the sample period. (Below we will consider variation over time.) In Table 1 we present the time-series means for each set of survey data. The results are ordered by length of forecast horizon, from the shortest-term one-week expectations, to the longer-term one-year expectations. The surveys cover a wide variet of sample periods as well. In the first column, averages of actual depreciation are reported. During the periods of the one-week and one-month MMS surveys, from October 1984 to February 1986, the dollar depreciated against the yen at an annual rate of 27.5 percent. During the period covered by the three-month MMS surveys as well as the three, six and twelve month Economist surveys, the rate of depreciation is much smaller. Column (2) reports corresponding averages of the survey expected depreciation. The time-series means of realized depreciation perform very poorly as measures of the investors' expectations reported in the surveys. In contrast to the considerable swings in the sign and magnitude of average actual spot rate changes, the survey consistently called for upward movements in the value of the yen against the dollar. The expectations are the same in sign, but larger in magnitude than the time-series averages of the forward discount reported in colume (3).

The last column in table 1 presents the risk premium on dollardenominated assets as implied by the surveys. Strikingly, during both periods of appreciation and periods of depreciation the risk premium is negative. Far from regarding the two assets as perfect substitutes, investors appear to be willing to sacrifice the substantially higher expected returns from holding yen in order to hold dollars. Indeed, the 


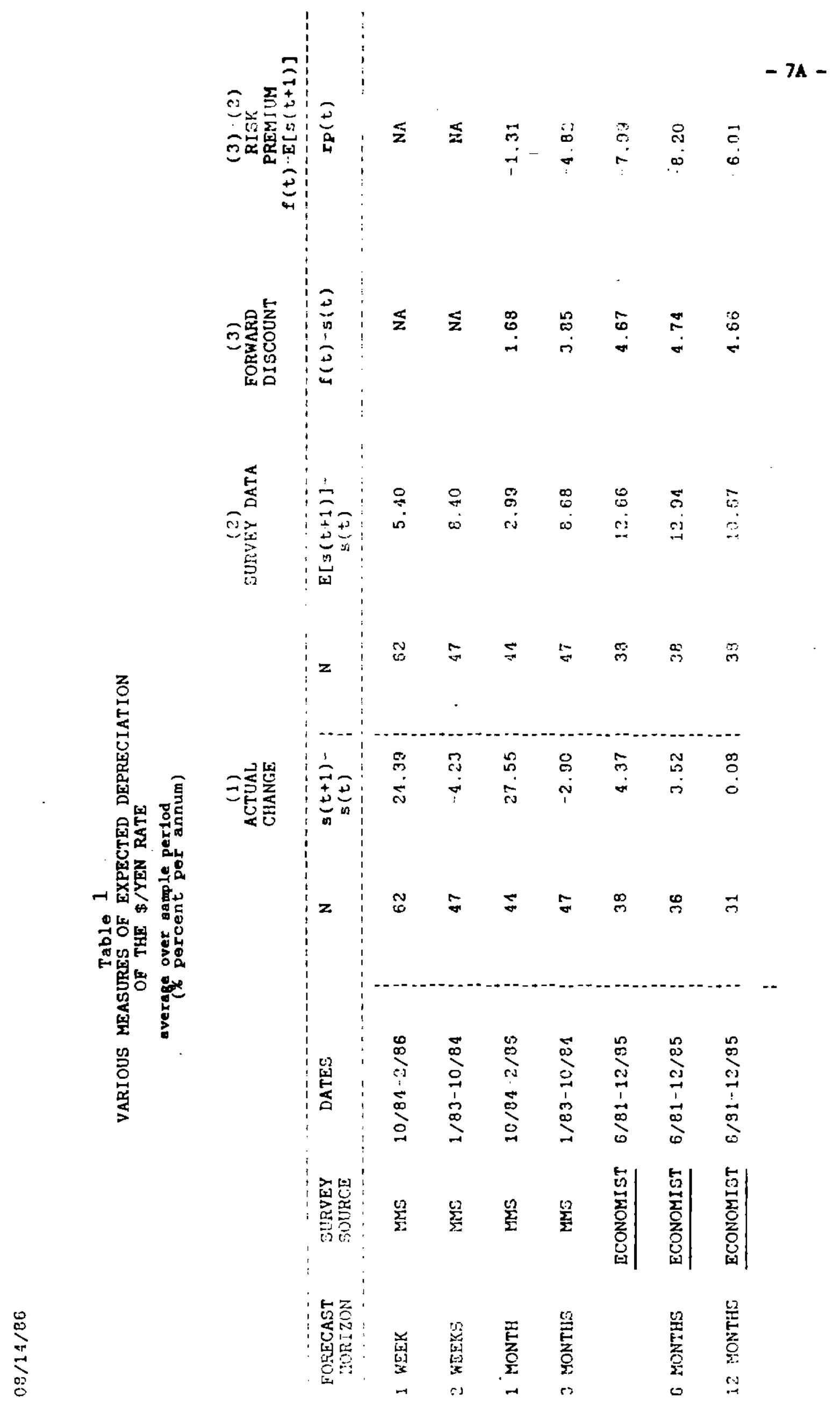




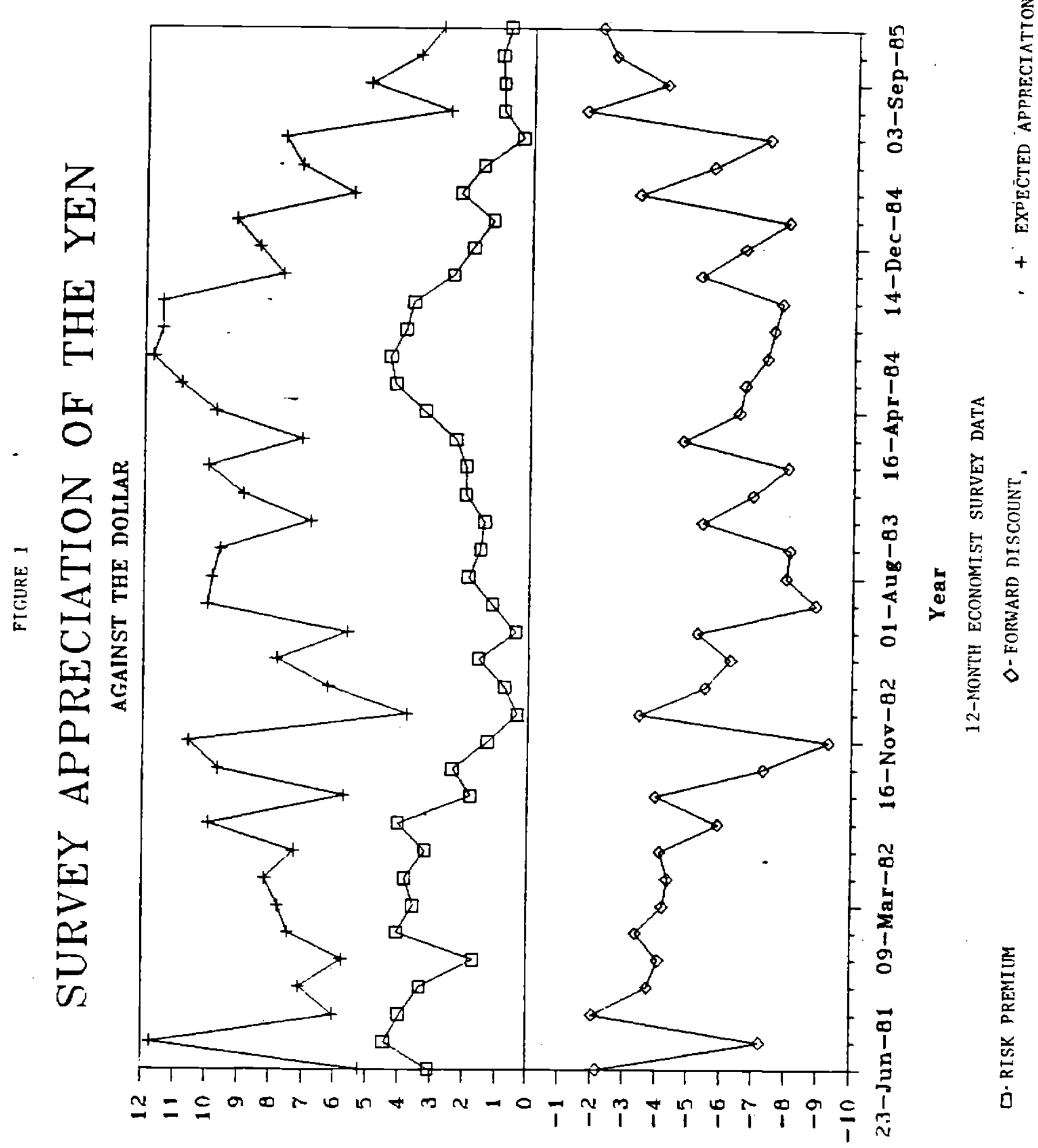

urnt de Iad ₹uasiad 
magnitudes are surprisingly large. In the three-month Economist data, for example, -respondents expected they could earn an add1tional 7.99 percent per annum on assets denominated in yen compared with dollars. It is hard to justify such large exchange risk premia using the theory of optimal portfollo choice with conventional estimates of risk-aversion (Frankel 1985, and Mehra and Prescott 1985).

One explanation proposed for why investors were wllling to hold dollars at lower expected rates of return is that the United States provided a "safe haven" frow capital controls and other political risks (for example, Dooley and Isard, 1985; but see Frankel and Froot, 1986). Grounds for this argument seem especially lacking vis-a-vis the yen: Japan was not directly involved in either the Latin American debt crisis or concerns of "Europessimism", and the 1980 s have been a period during which Japanese financial markets have been steadily liberalized, if anything reducing fears of prospective capital controls. Furthermore, only exchange rate risk should in theory be relevant, not factors relating to the political jurisdiction of Japan, because the spot and forward rates are determined offshore in the Euromarket. But whatever the reason, table 1 suggests that investors distinguish between assets denominated in different currencies, demanding a higher return on the yen than on dollars. This is also clear in Figure 1.

While the evidence so far indicates that a risk premium exists, it is not necessarily evidence that the risk premium varies over t1me. The proposition that the risk premium is time-varying rather than constant comes out of most of the conventional empirical ilterature on the forward 
market, as wit] as the theury of optimizing investors, and is also a property of models in which stertlized foreign exchange intervent ion has Important effects.

Thus we would also like to know whether changes in the forward discount indicate a changing risk premium. This ts prectsely the type of time-varying risk premium that the literature testing forward rate unblasedness has sought. 5 The degree to which changes in the forward discount reflect changes in the risk premium can be inferred from a regression of expected depreciation on the forward discount:

$$
\Delta s_{t+k}^{e}=\alpha+b f d_{t}^{k}+\varepsilon{ }_{\tau+k}^{k}
$$

The null hypothesis in equation (3) is that assets are perfect substitutes, i.e., $\alpha=0$ and $b=1$. The estimated coefficient, $\hat{b}$, converges in probability to:

$$
\begin{aligned}
b & =\operatorname{cov}\left(\Delta s_{t+k}^{e}, f d_{t}^{k}\right) / \operatorname{var}\left(f d_{t}^{k}\right) \\
& =1-\left[\operatorname{cov}\left(r p_{t}^{k}, f d_{t}^{k}\right) / \operatorname{var}\left(f d_{t}^{k}\right)\right] .
\end{aligned}
$$

A finding that $b$ is near zero or less than zero is evidence that changes in the forward discount reflect changes in the risk premium, while a finding that $b$ is near one is evidence that such changes in the forward discount reflect something else, namely equivalent changes in expected deprectation.

The conventional approach to testing equation (2) uses ex post spot rate changes to infer the behavior of the unobservable market expected

5Fama (1984), Hodrick and Srivastava (1984, 1986) and Froot and Frankel (1986) discuss whether changes in the forward discount primarily reflect changes in the risk premium or in expected depreciation. 
depreclation. Under the assumption of rational expectations, the future opot rate reallzatlons are vlewed as nolsy measures of Investors' expectations. Thls nolse is assumed to be uncorrelated with the forward discount, and therefore can be 1 dentifled with the resldual term in equation (3). Table 2 reports estlwates of equation (3), using ex post changes in the spot rate as the lefthand-side variable. 6 All of the polnt estlmates of $b$ are less than zero, and most are slgniflcantly less than one. The conventional approach would therefore seem to 1mply that changes in the forward dlscount predomlnantly reflect changes in the risk premi um.

Our alternative test of equation (3) uses the survey expected depreclation on the lefthand side, In place of the actual spot rate change. The existence of heterogeneous bellefs, the use of the medlan survey response, and the lack of perfect synchronization, are reasons to suspect that the surveys inay also be nolsy estlmates or market expectations. Now the error term in the regression equation may be interpreted as measurement error in the surveys. He make the assumption that thls measurement error is random, which is analogous to the assumption of rational expectations used in the conventional technlque above, 1.e.. that the expectation error is random.

6 All of the regressions in this paper are estimated using oLs. The Economost surveys, MS one-month and three-month surveys, and the AMEX twelve-month survey were conducted at intervals shorter than their respectlve forecast horlzons. Thls impl les that the error term in equation (2) 1 s serlally correlated even under the null hypothesls. Consistent estimates of the standard errors were obtained by the usual method of moments procedure (see Hansen and Hodrick (1980), or Froot and Frankel (1986) for a more detalled description). For additional information on the construction of the data sets used in thls paper, see the appendix to Frankel and Froot (1985). 


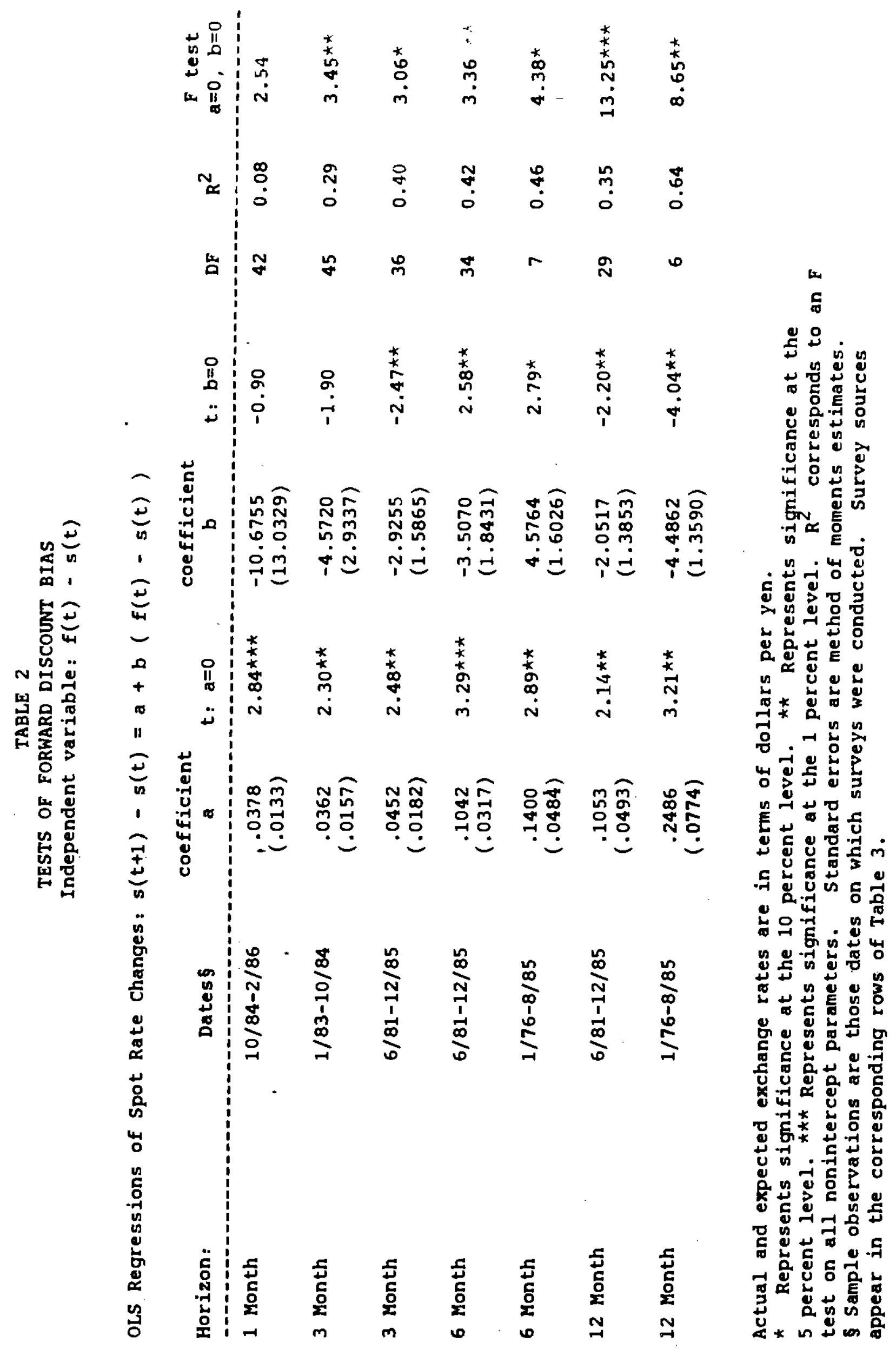


Though the two approaches are analogous, there are several reasons to prefer the surveys to the actual spot rate data in tests of equation (3). The first is that, under the hypothesis that both actual spot rates and the surveys contain only the market expectation plus purely random noise, the nolse element in actual spot rate changes turns out to be much larger than the noise element in the surveys. In Froot and Frankel (1986, table 3) we report estimates of the variances of actual and survey expected spot rate changes and find that the former is greater by a factor of 7 to 10. This implies that, for any given sample, a more precise estimate of $b$ may be obtained by using the surveys. A second reason to prefer the surveys is that they free us from imposing the restriction that there are no systematic prediction errors in the sample, a proposition that we would like to be able to test rather than impose. Such systematic errors, which the conventional technique must assume away, could occur because of a fallure of rational expectations, or because important events Which affect expectations did not happen to occur a representative number of times in the sample (the "peso problem"), rendering the ex post distribution of spot rate changes a blased estimator of the ex ante distribution.

Tests of equation (3) using the survey data on the lefthand side are reported in table 3 . In each of the seven data sets the estimates of $b$ are greater than those in table 2. In most cases we cannot reject the hypothesis that $b$ equals one. In other words, we cannot reject the hypothesis that the survey risk premia reported in table 1 do not vary over time. There is not even much sign that the risk premium on yen had an 


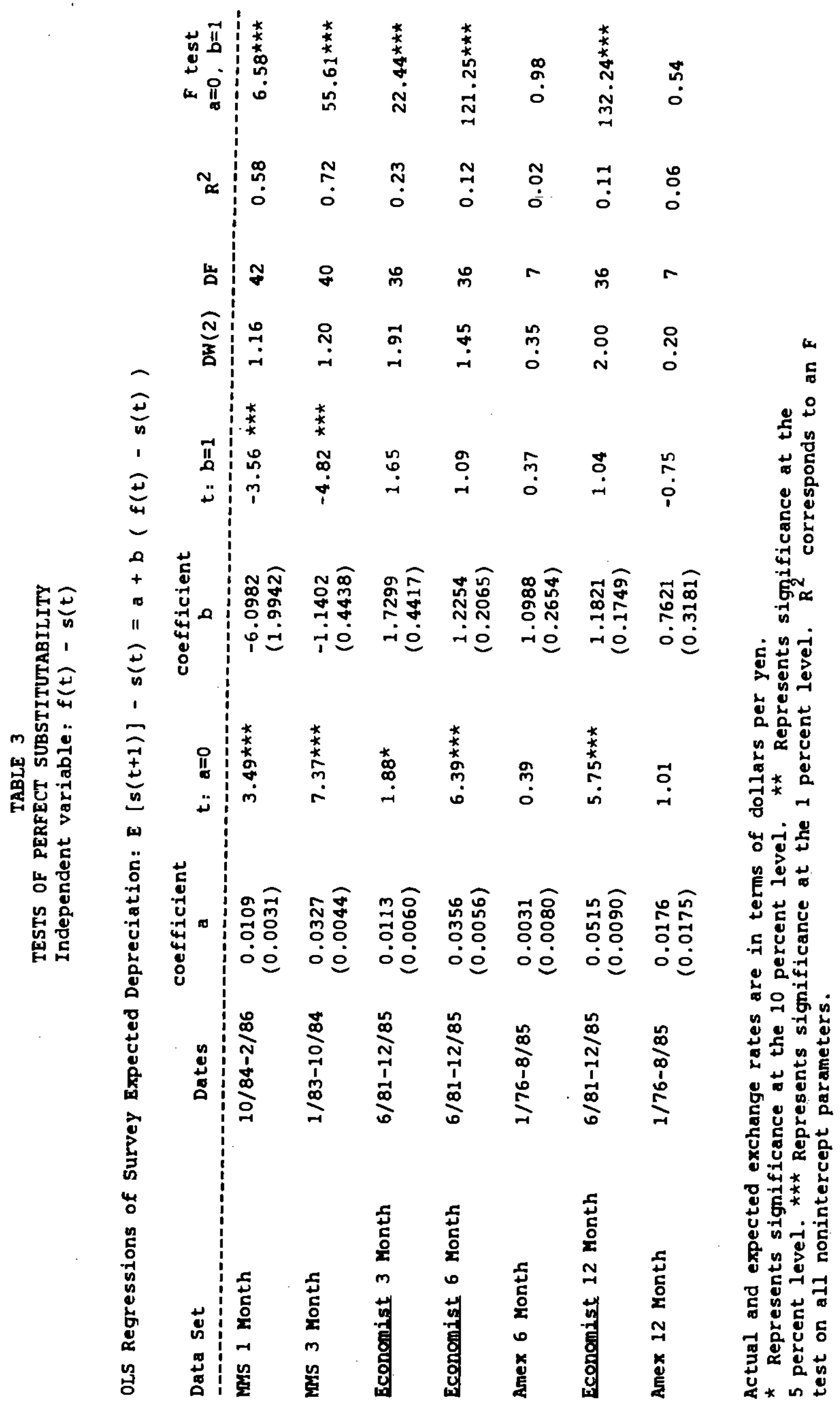


exogenous downward trend during the 1981-85 period, as 1 t would under the hypothesis that internationalization was causing investors around the world to become more willing to hold yen. (Figure 1 shows, on the negative axis, the risk premium on dollars, 1.e., the forward discount or interest differential minus the expected appreclation of the yen.) In all cases, however, we can reject the hypothesis of perfect substitutability, $a=0$ and $b=1$ jointly. In other words, the risk premium does show up in the constant tern.

To summarize, in Table 3 , as in Table 1, it appears that the ex post depreciation may be a very poor measure of expected depreciation. Table 3 provides evidence that changes in the forward discount reflect primarily changes in expected depreciation rather than changes in the risk premium .

\section{Models of Expected Depreciation}

The results from the first three tables suggest that there is information on expectations in the surveys which is not contained in either realized spot rates or forward rates. We may thus gain new insights by using this data source to reexamine several old formulations of exchange rate expectations that are standard to the 11 terature.7

A general framework for testing various specifications of expectations is to model expectations of the future spot rate as giving some weight to the contemporaneous spot rate as well as some weight to other variables in investors' information set. In each case below, our

7 The tests reported in this section are similar to those reported in Frankel and Froot (1985) for the dollar against five other currencies. But they did not include the results for the shorter-term forecast horizons. 
null hypothes1s w11l be that of stat1c expectations: investors place a weight of one on the contemporaneous spot-rate and a welght of zero on the other information, so that expected depreclation $1 \mathrm{~s}$ zero. The alternative hypothes1s depends on the preclse variable chosen to represent the "other" Information. Suppose, for example, that 1nvestors ass $1 \mathrm{gn}$ a welght of 8 to the lagged spot rate and a welght of $1-g$ to the current spot rate in forming the1r expectations of the future spot rate:

$$
s_{t+k}^{e}=(1-g) s_{t}+8 s_{t-k}
$$

where $s_{t}$ is the logarithm of the current spot rate. Subtracting $s_{t}$ from both sides we have that expected depreciation is proportional to the most recent change in the spot rate:

$$
\Delta s_{t+k}^{e}=-8\left(s_{t}-s_{t-k}\right)
$$

We term the model in equation (5) extrapo:ative expectations. If Investors place positive weight on the lagged spot rate, so that $z$ is positive, then equation (4) says that 1nvestors' expected future spot rate is a simple distributed lag. On the other hand, if 1nvestors tend to extrapolate the most recent change in the spot rate, so that $g$ is negative, then equation (5) may be termed "bandwagon" expectations. In th1s latter case a current appreciation by itself generates expectations of further future appreclation. By defining "speculation" as the buying and selling of yen in response to non-zero expected exchange rate changes, we can 
interpret a finding of $g>0$ as implying that speculation is stabilizing and a finding of $g<0$ as Implying that speculation is destabilizing.

Table 4 reports regression estimates of equation (5), using the survey expected depreciation as the lefthand-side varlable. The regression error can be Interpreted as random measurement error. Under the joint hypothesis that the mechanism of expectations formation is specified correctly and that measurement error is random, the parameter estimates are consistent. It snould be noted that the joint hypothesis is a particularly strong assumption because the spot rate appears on the right-hand-side; if a change in expected depreciation feeds back to affect both the contemporaneous spot rate and any element of the regression error, then the estimate of $g$ will be biased and inconsistent. However this is not a problem under our null hypothesis that expected depreciation is constant. The findings are once again ordered by the length of the forecast horizon. It is inmediately evident that the shorter-tern expectations -one week, two weeks and one month -- all exhibit large and significant bandwagon tendencies: that is, $g<0$. In the one-week expectations, for example, an appreciation of 10 percent in one week generates the expectation that the spot rate will appreciate another 2.4 percent over the next seven days.

In contrast with the shorter-term expectations, the longer-term results all point toward distributed lag expectations, the stabllizing case. Each of the regressions at the 6 and 12 month forecast horizons estimate 8 


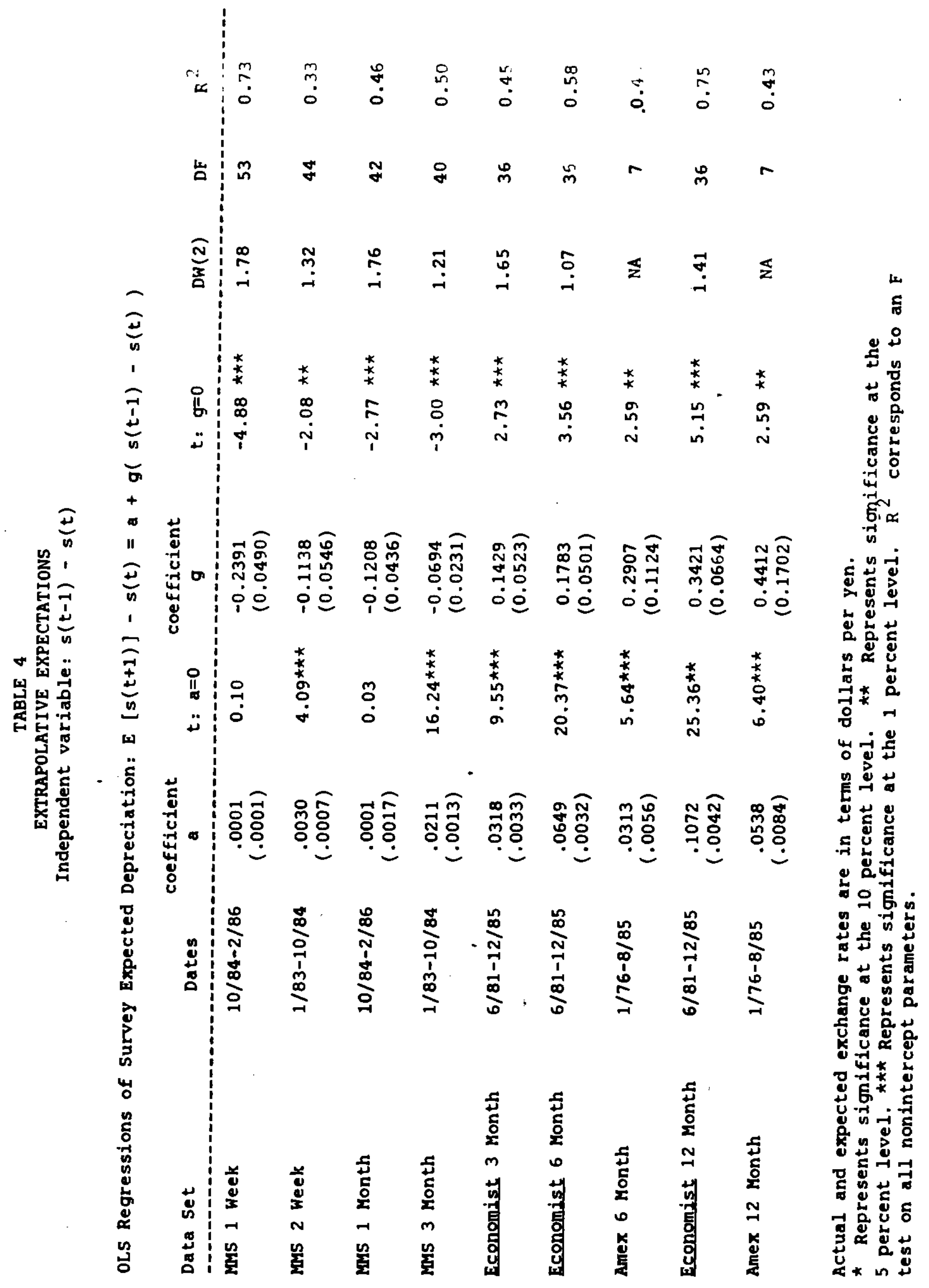


to be significantly greater than zero. $B$ The Economist 12 month data, for example, Imply that a current 10 percent appreciation by itself generates an expectation of 3.4 percent depreciation over the coming 12 months. Thus longer-term expectations feature a strongly positive welght on the lagged spot rate rather than complete weight on the contemporaneous spot rate, and in this sense are stablizing.

A second popular specification for the expected future spot rate is that it is a weighted average of the current spot rate and the long-run equilibrium spot rate, $\bar{s}$ :

$$
s_{t+k}^{e}=(1-\theta) s_{t}+\theta \bar{s}_{t}
$$

or in terms of expected depreciation:

$$
\Delta s_{t+k}^{e}=\theta\left(\bar{s}-s_{t}\right)
$$

If $\Theta$ is positive, as, for example, in the Dornbusch (1976) overshooting model, the spot rate is expected to move in the direction of $\bar{s}$. Expectations are therefore regressive. Alternatively, a finding of $\theta<0$ Implies that investors expect the spot rate to move away from the long-run equilibrium.

8 In Frankel and Froot (1986), we correct for the low Durbin-Watson statistics in similar regressions using five different currencies (and those in Tables 6 and 7) using a three-stage least squares estimation technique which allows for first order serial correlation in the residuals. The technique is not repeated here since the corrected results obtained in that paper are very similar to the uncorrected OLS o:timates. 


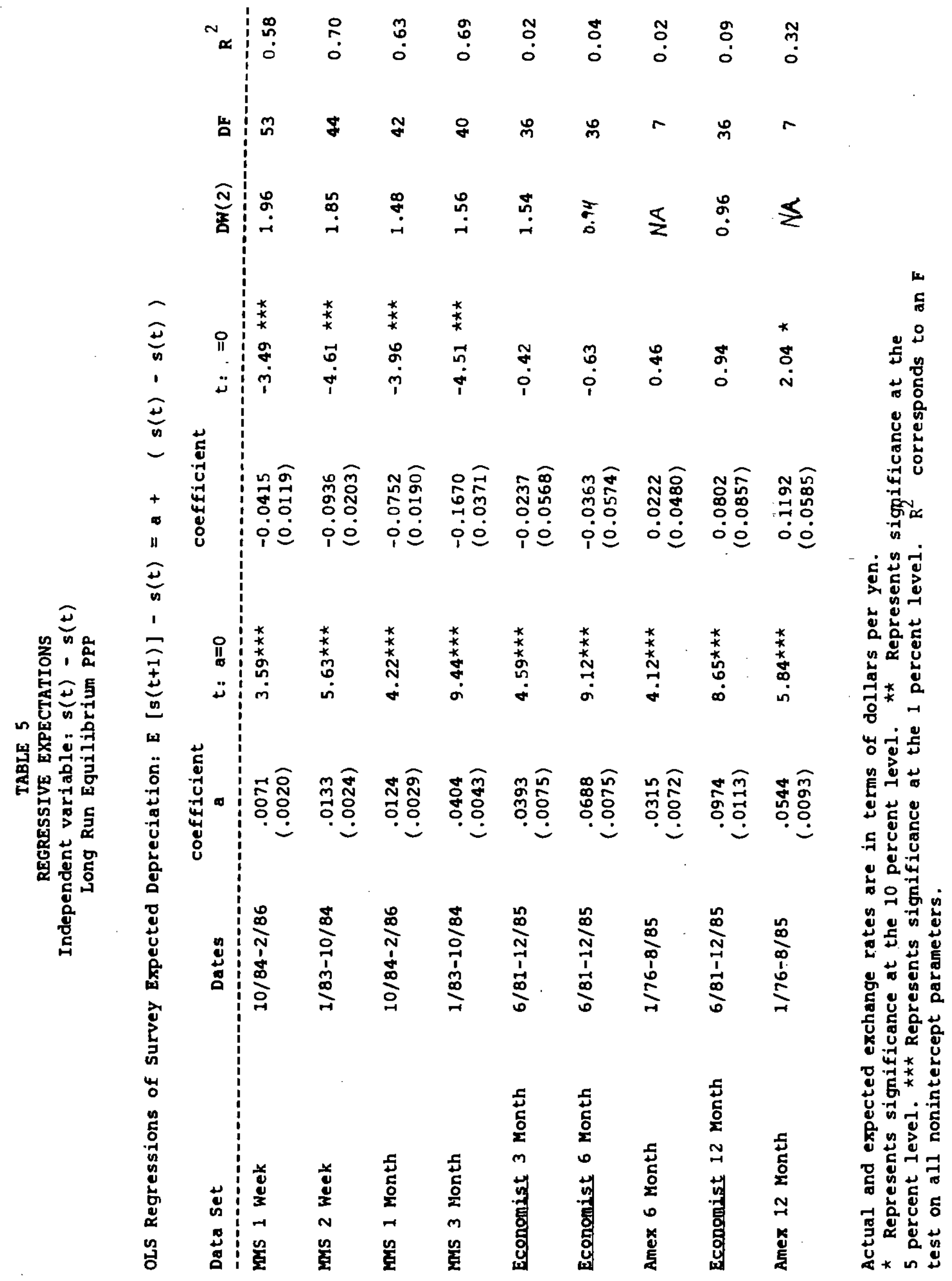


Table 5 presents tests of equation (4). Estimates of changes in $\bar{s}$ were calculated using CPI's to measure changes in the relative price levels In the United States and Japan, under the assumption of purchasing power parity (PPP). Once again, there is strong evidence that shorter-term expectations are formed in a manner different from longer-term expectations. The shorter forecast horizons all yield estimates of tnat $\theta$ are negative, additional evidence that shorter-term speculation may be destabilizing. Indeed, the 1-week data suggest that the contemporaneous deviation from the long-run equilibrium is expected on average to grow by 3 percent over the subsequent seven days. In other words, short-term expectitions are explosive. What about the longer-term horizons? In Frankel and Froot (1985) we found a nighly significant speed of regression at the longer-term horizons. The longer-term estimates of $\theta$ in Table 5 do not, however, exhibit regressivity for the yen that is as highly significant. Only the American Express 12-month data, which is available as far back as 1976. shows an estimate that is significant even at the 10 percent level. It may be that relative CPI's are not the appropriate indicator of the equilibrium yen/ dollar rate. It has been suggested that due to rapid productivity growth in Japan, Japanese producers gain in international competitiveness even to the extent that PPP is observed to hold. Marston (1986) demonstrates that even though estimates of real exchange rate changes using CPIs show real appreciation of the yen against the dollar over the last decade, estimates using manufactured goods priçes give a very different answer. 9

The final specification we consider is adaptive expectations. In

9See also Krugman (1986) and Johnson and Loopesko (1986). 


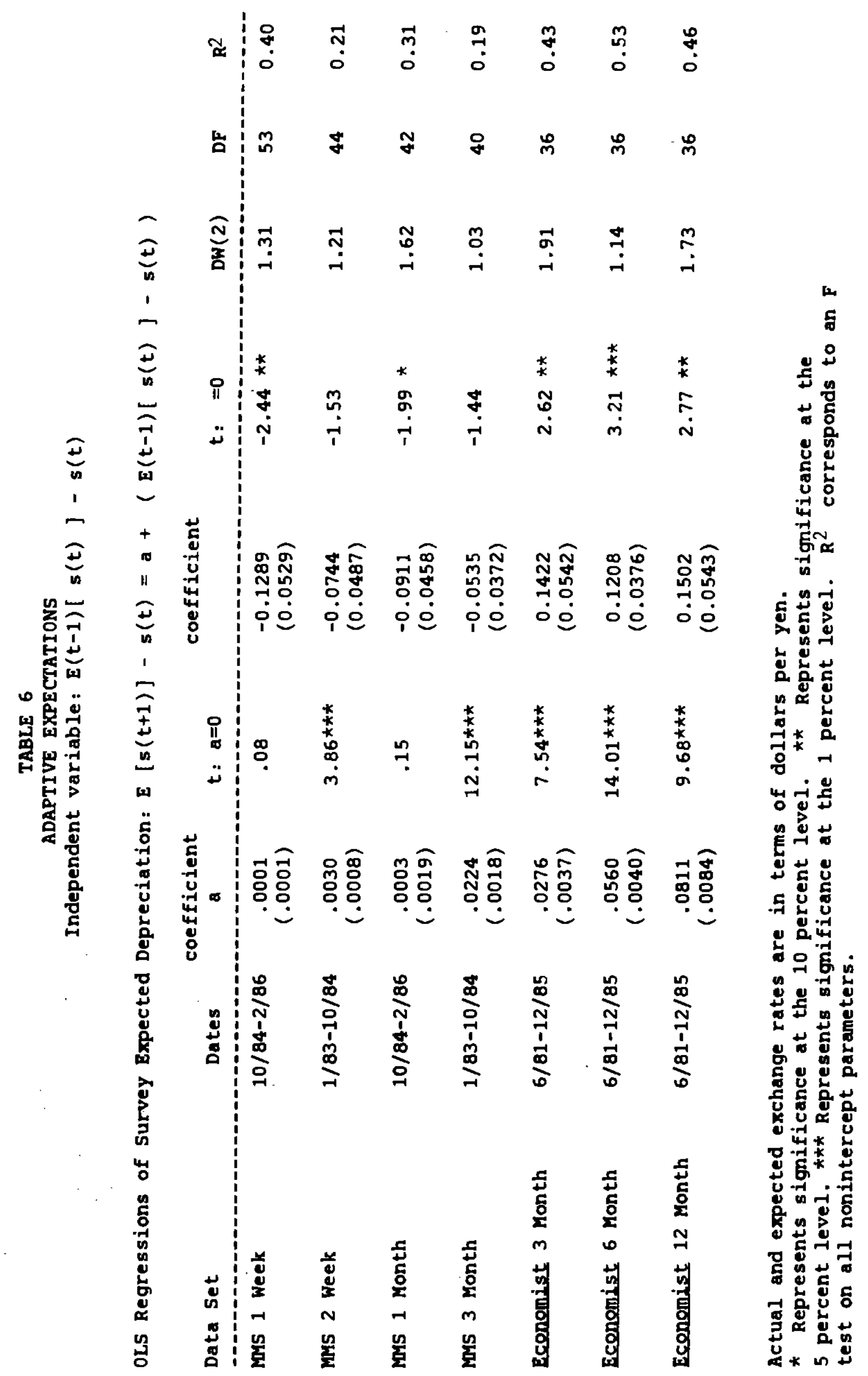


this case, agents are hypothesized to form their expectation of the future spot rate as a welghted average of the current spot rate and the lagged expected spot rate:

(8) $s_{t+k}^{e}=(1-\gamma) s_{t}+\gamma s_{t}^{e}$.

Expected depreciation is now proportional to the contemporaneous prediction error:

$$
\Delta s_{t+i}^{e}=\gamma\left(s_{t}^{e}-s_{t}\right)
$$

Table 6 reports estimates of equation (9). Once agaln, the welght placed on the variable other than the contemporaneous spot rate, in this case the lagged expectation, is sensitive to the forecast horizon of the surveys. Shorter-term expectations again appear to be strongly destablizing, while the longer-term expectations are significantly stabilizing. For example, the one-week data indicate that an unanticipated appreciation of 10 percent by itself generates an expectation of continued appreciation over the subsequent seven days of 1.3 percent. At the other extreme, the Economist 12-month data suggest that an unanticipated appreciation of 10 percent generates an of setting expectation of depreciation of 1.5 percent over the subsequent year. The results of Tables 4,5, and 6 suggest that in all three of our standard models of expectations--extrapolative, regressive and adaptive--short-teris and long-tern expectations behave very differently 
from one another. Longer-term expectations consistently appear to be stabllizing, while shorter-term forecasts seem to have a destabilizing nature. Within each of the above tables, it is as if there are actually two models of expectations operating, one at each end of the spectrum of forecast horizons, and a blend in between.

It may be that each respondent is thinking to himself or herself, "I know that in the long run the exchange rate must return to the equilibrium level dictated by fundamentals. But in the short run I will ride the current trend a little longer. I only have to be careful to watch for the turning point and to get out of the market before everyone else does." If this is the logic of the typical investor, then he is acting irrationally; it is not possible for everyone to get out before everyone else. But so $f$ ar we have not presented any evidence that the actual spot process behaves differently from investors' expectations. We consider such evidence in the following section. 10

IV. Rationality of the Survey Expectations

Now that we have a sense for the behavior of the survey expected depreciation, we turn to an analysis of whether the predictable component

10 One possibility is that the MMS short-tern survey is picking up predominantly the expectations of ploor traders, people who buy and sell currency on a short-term basis, and that the other two, longer-term, surveys are plcking up predominantly the expectations of investors who have a longer-term perspective. Under this interpretation, it may be that the traders have developed the habit of ignoring economic fundamentals in their expectations formation, rather going with time series trends (as in "chartism" or "technical analysis"), and that the latter group pays more attertion to fundasentals. The chartist/fundamentalist dichotomy and its implications for the determination of the value of the dollar in the 1980s are pursued in Frankel and Froot (1986). 


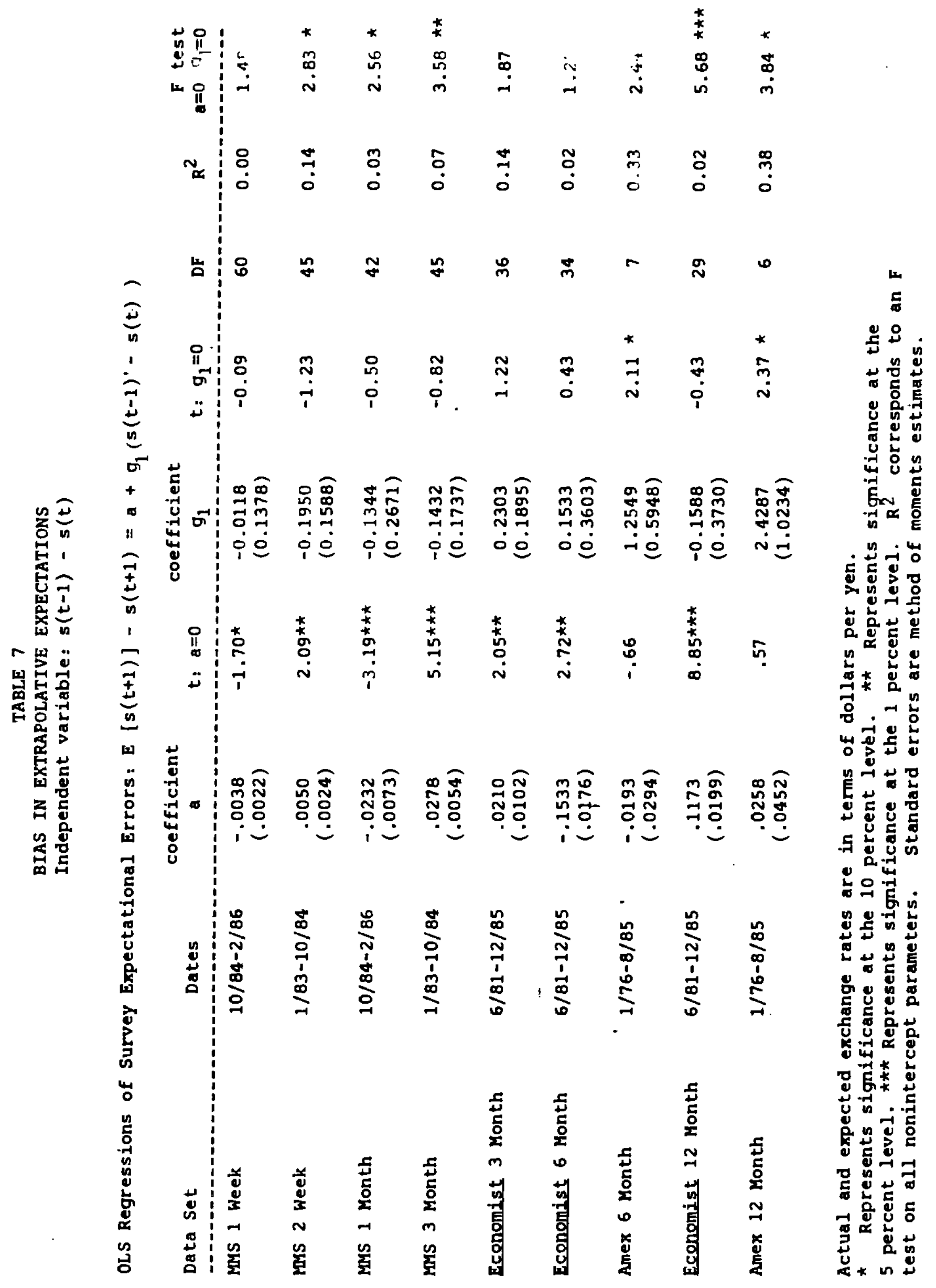


of the true spot process behaves in the same way, i.e., whether expectations are rational. One way to proceed would be to re-estinate each of the models given in equations $(5)-(8)$, only now using realized depreciation as the lefthand-side variable. The hypothesis that expectations are rational would imply that these regressions should yield coefficients that are statistically indistinguishable from those obtained earlier using the surveys on the lefthand side. A more direct way to test the same hypothesis is to regress the difference between the survey expectation and the actual future spot rate, the survey prediction error, on each set of regressors in equations (5)-(3). Under the null hyp.thesis that expectations are rational, this prediction error should be purely random (conditionally independent of all information available at time $t$ ) and therefore should be uncorrelated both with the righthand-side variables and with past errors. We test whether the coefficients are jointly zero. Table 7 reports regressions of the survey prediction errors on the most recent change in the spot rate. The estimated $F$ statistics give some evidence of systematic expectational errors: five of the nine data sets reject the joint hypothesis that both the constant and slope coefficients equal zero. In view of the discussion in the previous section, an inspection of the slope coefficient, $g$, can help us to determine whether investors place the correct weight on the lagged spot rate. A finding of $g_{1}>0$ would indicate that expectations are "insufficiently" extrapolative: investors give too much weight to the lagged spot rate and too little weight to the contemporaneous spot rate relative to what is rational. Conversely, a finding of $g_{1}<0$ would indicate 


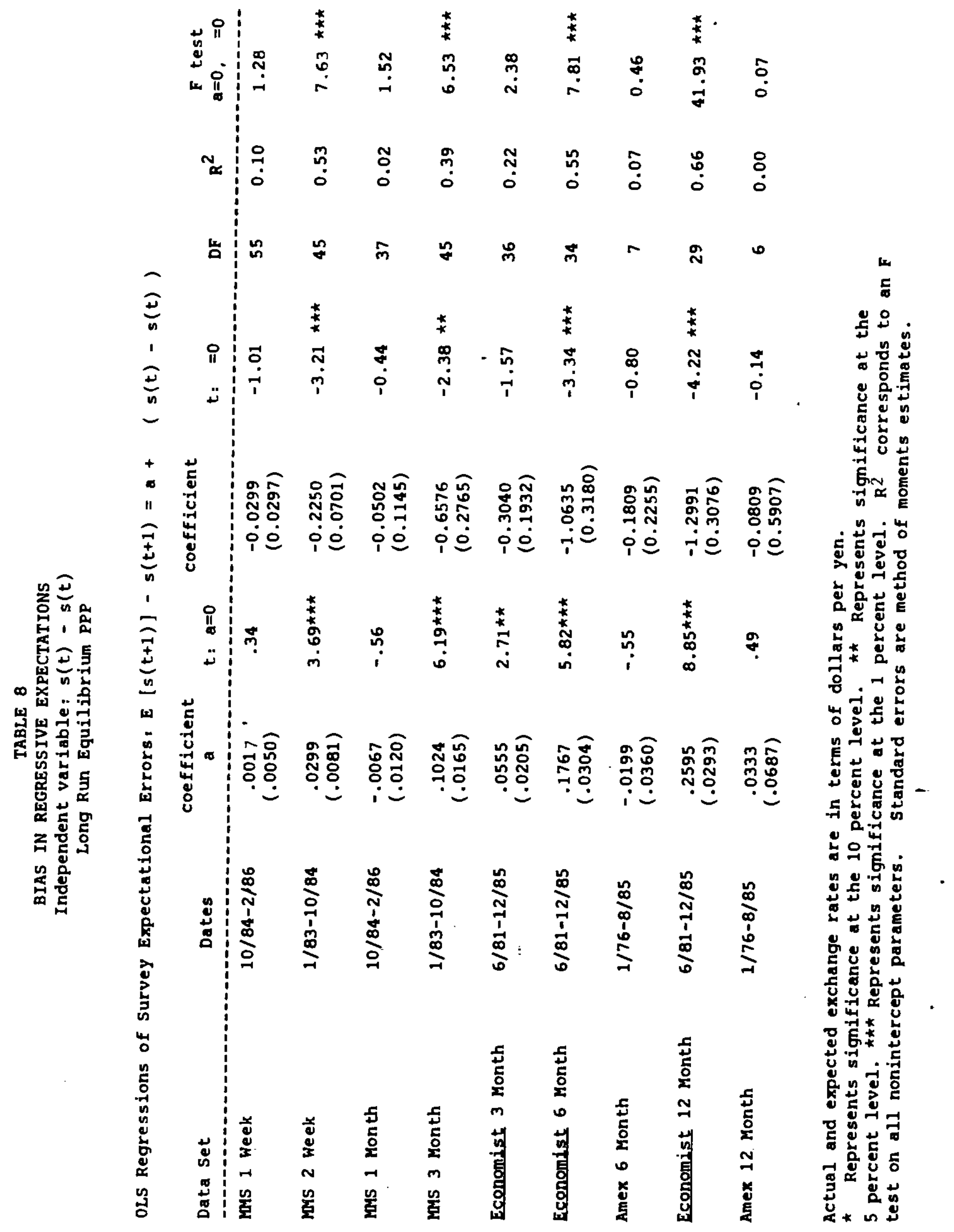




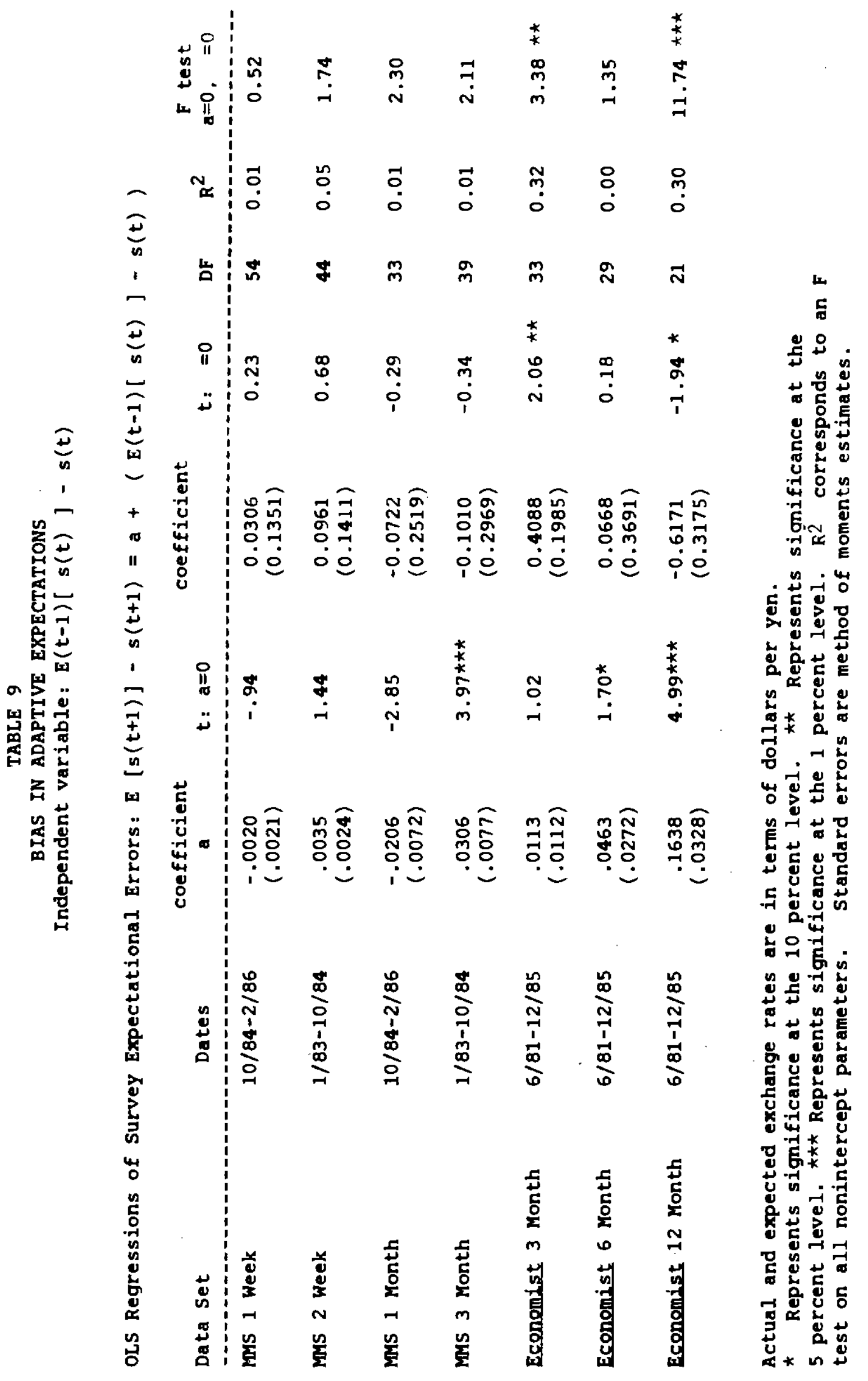


that expectations are "overly" extrapolative. Table 7 suggests that predictions at the shorter forecast horizons tend to be overly extrapolative, while those at the longer horizons are insurficientiy extrapolative. Such a pattern suggests that the contrast in Table 5 between the behavior of short-term and long-term expectations is too extreme relative to what the actual process generating spot rate changes would predict. Few estimates of $\mathbf{B}_{1}$, however, are significantly different from zero. There is thus not enough evidence so far to conclude that, at any of the reported forecast horizons, investors place too little or too much welght on the lagged spot rate relative to what is rational.

In Table 8 we test whether investors' expectations give the correct weight to the long-run equilibrium spot rate, $\bar{s}$. Here the results are surprisingly consistent across all of the forecast horizons: expectations seem to insufficiently regressive in that they give less weight to $\bar{s}$, and therefore more welght to the contemporaneuss spot rate, than does the true process governing the behavior of the spot rate. In Table 9 we perform the analogous test using lagged expectational errors on the righthand side. In this case, the alternative hypotheses are that expectations are either overly or insurficiently adaptive. As in Table 7 . the results in Table 9 do not suggest any clear tendency on the part of investors to give too much or too little weight to the most recent expectational prediction error.

The tests of rational expectations presented so far in Tables 7-9 are appropriate when we take as given the specific models of expectations formation discussed in the previous section. Each regression 
was deslgned to test whether investors assign the correct weight to a single element in their inforidation set when predicting the level of the yen/dollar rate. If, however, both expectations and the true spot process depend on other unspecified infortation, then the above tests of rationality are not necessarily the most enlightening nor the most powerful. A more robust test would ask whether expectations assign too little weight to the contemporaneous spot rate and (by default) too much weight to all other variables in their information set. This test is performed by regressing the survey prediction error on the survey expected deprectation:

$$
s_{t+k}^{e}-s_{t+k}=a+b\left(s_{t+k}^{e}-s_{t}\right)+\varepsilon_{t+k},
$$

and testing the hypothesis that the coefficients are jointly zero. The alternative hypothesis is that investors place too much (or too little) weight on variables otiner than the contemporaneous spot rate relative to what is rational. Following Bilson (1981), we tern this alternative hypothesis "excessive speculation", because investors could improve their forecasts by consistently reducing toward zero their expectations of depreciation.

Table 10 reports our estimates of equation (10). Here we find much more evidence of systematic expectational errors in the surveys. All but one of the data sets reject the hypothesis that the constant and slope parameter are jointly zero. Four of the seven estimates of $b$ are also statistically different from zero, so there is considerable evidence of excessive speculation. Unlike the results of the preceding tests of 


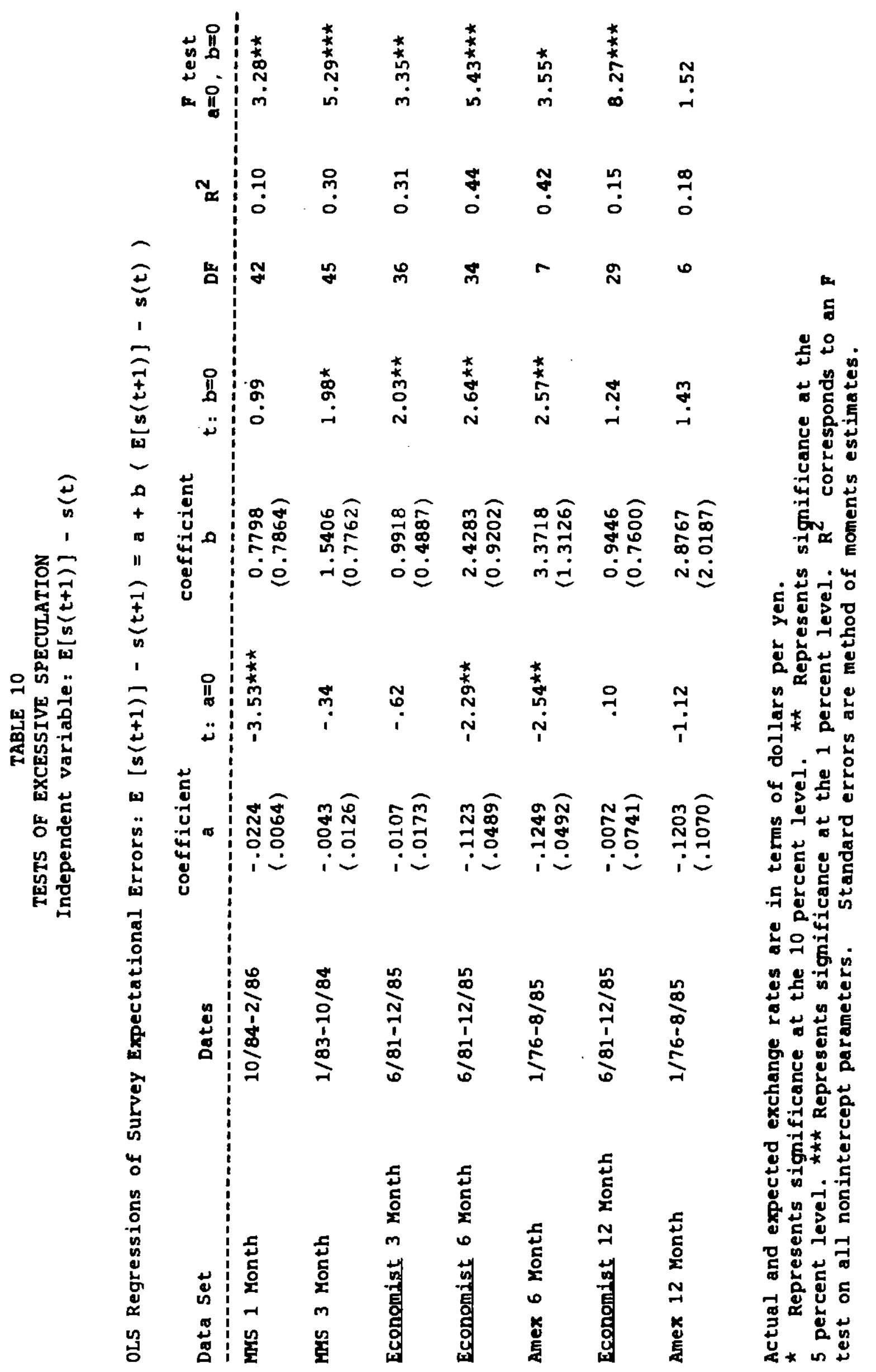


ratlonality, our estimates here are uniformly positive and do not appear related to the length of forecast horizon. In every case we are also unable to reject the hypothesis that $b=1$, which would imply that the expectations contain no useful information at all as to the future spot rate, 1.e., that the spot rate follows a random walk. We mentioned earlier the possibllity of measurement error in the survey data. In any of the regression equations where the expectations variable appears only on the lefthand side, namely the cases of extrapolative expectations ( $\mathrm{Tables} 4$ and 7 ) and rejressive expecations (Tables 5 and 8 ) random measurement error does not impair the regression estimates. But in the case of adaptive expectations (Tables 6 and 9), as well as in the present case of excessive speculation (Table 10), the expectations variable appears also on the righthand side of the equation, so that measurement error would affect the estimates.

When the issue of possible randon measurement error in these regression equations is addressed the results are qualitatively unchanged. In the test for excessive speculation we can eliminate the problem of measurement error (so long as it is random) by using the forward discount as the righthand-side variable. Table 11 again shows systematic expectational errors: Investors could do better by routinely betting against the forward discount. 11

11 See Froot and Frankel (1986) for further explanation. In the case of estimating adaptive expectations, we would argue that the bias introduced, though nonzero, is small, because the variance of actual spot rate changes is approximately 10 times larger than the variance of expected depreciation (Table 3, 101d.). 


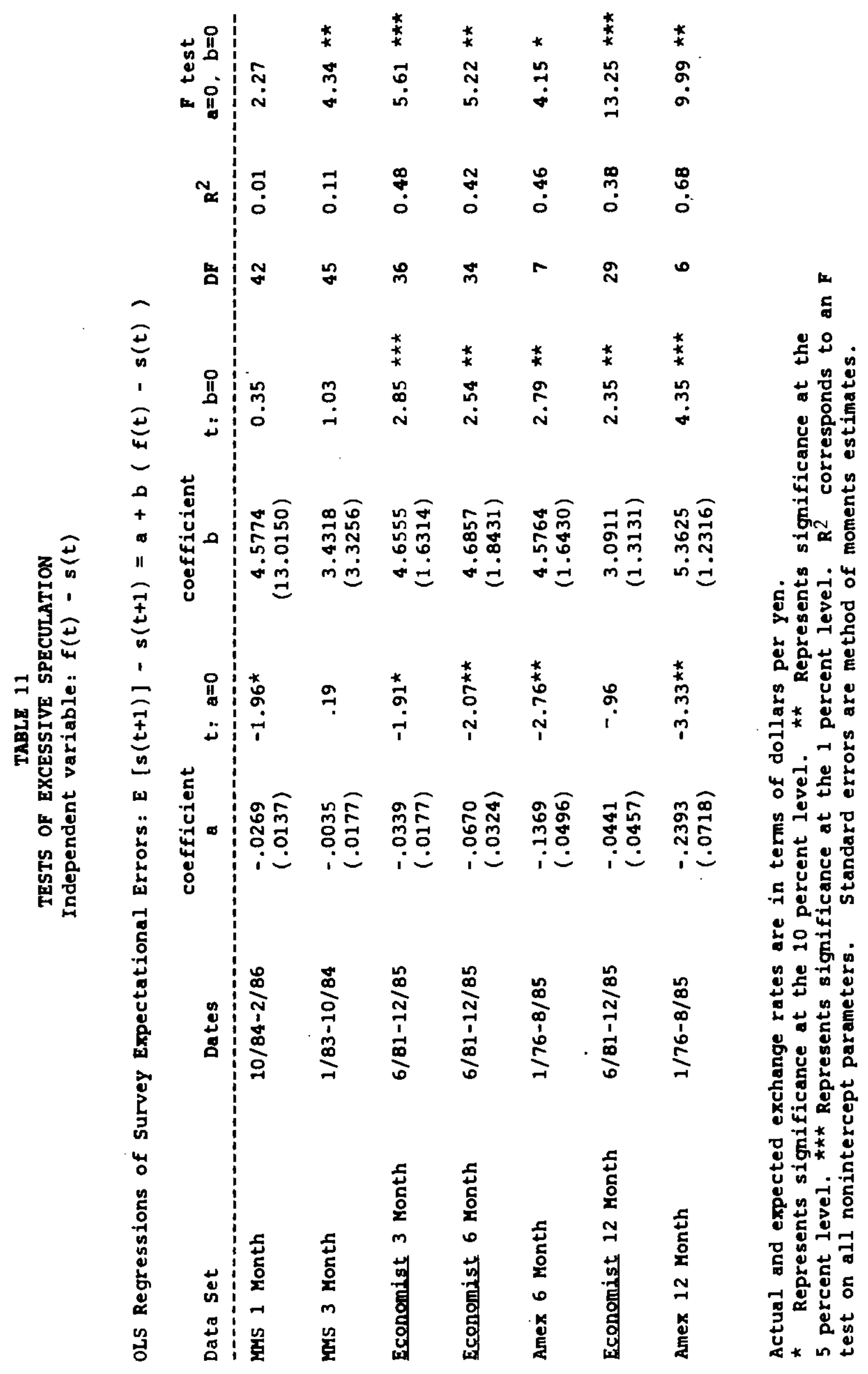




\section{v. Conclusions}

(1) The survey data on exchange rate expectations appear to contain new information about market expectations which is not apparent from either ex post spot rate changes or the forward discount. Our measures show that, despite the large swings in both directions in the value of the yen since 1980, the surveys consistently called for a large appreciation of the yen against the dollar.

(2) These measures of expected appreciation are also substantially in excess of the forward prenium. An Implication is that investors were willing to accept a lower expected rate of return on dollar assets than on comparable assets denominated in yen.

(3) Contrary to what is comonly assumed in most rodels in which sterilized foreign exchange intervention is effective, variation in the forward discount does not reflect a statistically significant degree of variation in the risk premium.

(4) Variation in the forward discount primarily reflects, Instead of changes in the risk premium, changes in expected depreciation.

(5) The expectations given in the short-tern surveys exhibit bandwagon effects, which could imply that short-term speculation is destabiliaing.

(6) Expectations at longer-term horizcns, in ccrirast, appear to put less than rull weight on the contemporaneous spci $r=t$ and positive weight on 
Beveral other vartables such as the lagged spot rate, the long-run equilibrium spot rate, and the lagged expected spot rate.

(7) Investors could improve both thetr short-term and their long-term forecasts by reducing the absolute magnitude of expected depreclation toward zero. This finding of "excesstve speculation" would also follow from the result that expected deprectation is not zero together with the popular hypothesis that the true spot process follows a random walk. 


\section{References}

Amano, Akiniro, 1986. "Japan's External Imbalance and Exchange Rates." U.S. - Japan Consultative Group on International Monetary Affairs, 01so, Japan, July 11-13.

Bilson, John, 1981. "Profitability and Stability in International Currency Markets." NBER Working Paper No. 664, April.

Dooley, Michael and Peter Isard, 1985. "The Appreciation of the Dollar: An Analysis of the Safe-ilaven Phenomenon," International Monetary Fund DM/85/20, April.

Fama, Eugene, 1984. "Forward and Spot Exchange Rates," Journal of Monetary Economics, 14, pp. 319-338.

Frankel, Jeffrey, 1982. "In Search of the Exchange Risk Premium: A Six-Currency Test Assudinz Mean-Variance Optimization," Journal of International Money and Finance, 1, pp. 255-274.

, 1985. "The Dazzling Dollar." Brookings Papers on Economic Activity, 1, pp. 199-217.

Frankel, Jeffrey and Kenneth Froot, 1985. "Us1ng Survey Data to Test Some Standard Propositions Regarding Exchange Rate Expectations." NBER Working Paper No. 1672. Revised as IBE? Working Paper No. 86-11, University of California, Berkeley, May 1986. Forthcoming, American Economic Review.

- 1986. "The Dollar as a Speculative Bubble: A Tale of Fundamentalists and Chartists," NBER Working Paper No. i354, Marein. First half in Marcus Niallenberg Papers in International Finance $1 ., 1$. Second half forthcoming in Econocic Record.

Froot, Kenneth and Jeffrey Frankel, 1986. "Interpreting Tests of Forward Discount Bias Using Survey Data on Exchange Rate Expectations, "NBER Working Paper No. 1963, June.

Fukao, Mitsuhiro. 1983. "The Theory of Exchange Rate vetermination in a Multicurrency World," The Bank of Japan, Monetary and Economic Studies, Vol. 1, No. 2, October, pp. 55-110.

1985. "The Effectiveness of Coordinated Intervention," p. 16-63 in T. Hosomi and M. Fukao A Second Look at Foreign. Exchange Market Interventions, Japan Center for International Finance Study, No. 3. April.

and Takashi Okubo, 1984. "International Linkage of Interest Rates: The Case of Japan and the tinited States," International Economic Review, 25 1, Feb. 
Hansen, Lars and Robert Hodrlck, 1980. "Forward Rates as Optinal Predictors of Future Spot Rates: An Econometric Analysis." Journal of Political Economy, 88, October, pp. 829-853.

Hodrick, Robert and Sanjay Srivastava, 1984. "An Investigation of Risk and Return in Forward Forel gn Exchange." Journal of International Money and Finance," 3, Apr11, pp. 5-30.

1986. "The Covariation or Risk Premiuns and Expected Future Spot Rates." Journal of International Money and Finance," 3, April, pp. 5-30.

Ishlyama, Yoshlhlde, 1985. "The Yen/Dollar Exchange Rate: St1ll a Puzzle." U.S. - Japan Consul tat I ve Group on Internat Ional Monetary Arfairs, Washington, D.C., Oct.

Ito, Takatosh1, 1984. "Use of (Time-Domain) Vector Autoregressions to Test Uncovered Interest Parity." University or Minnesota, September. 1 1986. "The Intra-Dally Exchange Rate Dynamics and Monetary Policles after G5." U.S. - Japan Consul tat1 ve Group on International Monetary Affalrs, 01so, Japan, July 11-13.

Johnson, Manuel and Bonnle Loopesko, 1986. "The Yen-Dollar Relationsh1p: A Recent Historical Perspective." International Finance Discussion Paper Series No. 288, Federal Reserve Board, Washington, D.C., June.

Krugman, Paul, 1986. "Is the Japan Problem Over?" Conference on Trade Frictions, NYU Center for Japan-U.S. Buslness and Economlc Studies, April. NBER Working Paper No. 1962, June.

Marston, R1chard, 1986. "Real Exchange Rates and Productivity Growth In the Unlted States and Japan." American Enterprise Institute Conference on Real-Financlal Linkages, January. NBER Working Paper No. 1922, May.

McKenzle, Colin, 1986. "Issues in Forel gn Exchange Pollcy in Japan: Sterillized Intervention, Currency Substitution and Financial Liberalization." Ph.D. Dissertation; Australian National University.

Mehra, R. and E. Prescott, 1985. "The Equity Premi um: A Puzzle," Journal of Monetary Economics, 15, pp. 145-161. 